\title{
Research
}

\section{The Role of Indigenous Ecological Knowledge in Managing Rangelands Sustainably in Northern Iran}

\author{
Mehdi Ghorbani ${ }^{1}$, Hossein Azarnivand $^{1}$, Ali Akbar Mehrabi ${ }^{2}$, Mohammad Jafari $^{1}$, Hooshang Nayebi $^{3}$ and Klaus Seeland $^{4}$
}

\begin{abstract}
Pastoralists' knowledge of adaptive rangeland management in Iran has long been only selectively analyzed and documented. This study attempts to rectify that by outlining the indigenous ecological knowledge of the pastoralists of Nariyan village in the Taleghan region of northern Iran, and by evaluating the influence of such knowledge on rangeland management. Local herd owners operate according to traditional herding practices; their knowledge of rangeland plants and principles of sustainable rangeland management is indigenous and is based on centuries of experience and observation. Their in-depth knowledge covers the medicinal properties of various local plant species and the palatability of the most salient forage species in terms of sustaining the sheep and goats that are their livelihood. This study investigates some of the traditional strategies of rangeland management used in the Taleghan region, the rationale and timing of livestock rotation in the rangelands, local landscape classification, and local know-how in animal husbandry, all of which are indispensable in contributing to the pastoralists' survival and maintenance of the local environment.
\end{abstract}

Key Words: adaptive management; ecological memory; grazing management; indigenous ecological knowledge (IEK); pastoralists; rangeland management; rangeland utilization; Taleghan region, Iran

\section{INTRODUCTION}

Indigenous ecological knowledge (IEK) has played a key role in the economic and cultural development of humankind for millennia. It continues to plan an important role predominantly, but not only, but in rural and traditional societies of developing countries and to a certain extent in remote regions of economically developed countries (Seeland and Schmithüsen 2000). This kind of knowledge is grounded in peoples' perceptions of and experience in an environment at a given time, through a continued process of observation and interpretation. It can also be thought of as "... human lifeexperience in this distinct natural and social compound, within this unique local and contemporary setting" (Seeland 2000).

Indigenous ecological knowledge represents “. . . an accumulation of knowledge, practice, and belief, evolving by adaptive processes ..." that is transformed from generation to generation through cultural transmission (Berkes et al. 2000, Gemedo-Dalle et al. 2006). It “ . . . is not a ubiquitous knowhow everybody has and neither is it shared equally by all inhabitants of a locality nor is it a standardized, comprehensive account of 'what is known' in a particular socio-cultural setting" (Seeland 2000). For herds comprised of sheep and goats, we want to investigate whether this kind of ecological knowledge regarding the grazing capacity, time of grazing, and distribution of livestock in the rangelands corresponds with current ecological theories. Several anthropologists have claimed that this is indeed the case: i.e., that indigenous methods of rangeland conservation and communal rangeland management have proven to be sustainable (Homewood and Rodgers 1989, Galaty and Johnson 1990, Fratkin 1997).
Pastoralists, through their practical experience and ongoing relationship with their environment, are capable of successfully categorizing landscapes with respect to seasonal use and grazing capacity, as has been reported by modern ecologists (Oba and Kotile 2001). In this study, the indigenous ecological knowledge of pastoralists in Nariyan village in the Taleghan region of northern Iran is analyzed with respect to rangeland conditions, plant species and their uses, domestic animals, climate, herd conservation, management of livestock grazing throughout the year, and division of rangeland. Furthermore, the ecological memory of pastoralists-such as their ability to recognize the animals, know their owners, and apply special terms, even when the animals are in a large herd - is referred to as a kind of finesse and emotional understanding that comes from the pastoralists' personal experiences, observations, and habits in an almost life-long process of constant interaction with their surroundings.

Several researchers have stated the role of pastoralists' ecological knowledge as it relates to the utilization of rangelands (Spooner 1973, Nyerges 1982, Spooner 1982, Niamir-Fuller 1995, Bollig and Schulte 1999, FernandezGimenez 2000, Spencer 2004, Roba and Oba 2009). The ecological knowledge of pastoralists is comprised of perceptions that are related to the interactions that occur between humans and the environment; collectively, the perceptions help the pastoralists manage the ecosystems in a sustainable manner (Knapp and Fernandez-Gimenez 2008). For instance, pastoralists have a rich knowledge of the traditional methods of rangeland assessment, which in turn influences patterns of land use (Mills et al. 2002), or they can

\footnotetext{
${ }^{1}$ Faculty of Natural Resources, University of Tehran, Iran, ${ }^{2}$ Department of Watershed Management, Science and Research Branch, Islamic Azad University, Tehran, Iran, ${ }^{3}$ Faculty of Social Sciences, University of Tehran, Iran, ${ }^{4}$ ETHZ, Institute for Environmental Decisions - Group Society, Environment and Culture, Zürich, Switzerland
} 
use it to monitor rangeland conditions (Homewood and Rodgers 1991) and determine the grazing capacity for different livestock species (Cotton 1996). But the modern science of rangeland management has hitherto often neglected pastoralists' knowledge (Brown 1971) and thus has left a relevant potential resource underrated if not unused. Mysterud (2006), for instance, has criticized scientific carrying capacity models as alien to the rationale of pastoralists and therefore of little value in the context of their knowledge. Indigenous ecological knowledge among pastoralists also plays an essential role in the sustainable rehabilitation of rangelands (Gemedo et al. 2006, Forbes et al. 2009) thus strengthening the rangelands' natural capacity for resilience. Previous studies have shown new types of grazing management (Fernandez-Gimenez 2000, Oba and Kaitira 2006, Allsopp et al. 2007, Muller et al. 2007), emphasizing that the pastoralists, through indigenous ecological knowledge, have identified plants that are meeting the particular grazing habits of their herds in the plants' growing seasons (Fernandez-Gimenez 2000).

\section{BACKGROUND}

\section{Rangeland Management in Iran after the Nationalization of Rangelands and Forests Act of 1963}

The pastoralists of Nariyan village have traditional methods of herding and land use that differ from those of other pastoral communities in northern Iran. These methods have been formed all over Iran over long periods of time - as Sunderland (1968) has extensively elaborated in his environmental history of Iranian pastoralist culture-according to the local environmental conditions and the societal organization of animal husbandry. The pastoralists manage their flocks by uniting them seasonally in larger herds for increased yields in dairy production and to share in the limited resources of grazing land. We investigated the rationale of their adaptive land-management system and embarked on an analysis of the various layers of applied ecological knowledge.

Rangeland management in Iran underwent major changes following the Nationalization of Rangelands and Forests Act of 1963. Forests and rangelands were nationalized by the government and could thereafter be leased to individuals and groups of herders. All over Iran, and thus in the Taleghan region, pastoralists had to apply for grazing permits to use their former rangelands. These grazing permits, which were issued by the Bureau of Rangeland Technical Administration of the Forests, Rangelands and Watershed Management Organizations, define the boundaries of the rangeland to be used, the grazing seasons, and the grazing capacity. "In the initial years, grazing licenses were issued for a period of ten years. In the 11 th year, the land was evaluated and if the range condition had improved, the license was renewed for a period of thirty years" (Badripour et al. 2006). The results of the land reform were a loss of the traditional methods of rangeland management which led to rangeland degradation and a decline of the nomadic livelihood system in many regions of rural Iran. Pastoralists' user rights were more often than not neglected and the new regulations lacked an understanding of the human role in rangeland management (Abolhassani 2011).

\section{Study area}

Our case study of rangeland utilization around Nariyan village shows, relative to the developments in other rural regions of Iran, how pastoralists have protected their traditional systems of rangeland management over the past 70 years-despite these years having been a phase of transition and political turmoil after the abdication of Reza Shah in 1941, and despite the adverse effects that resulted from the 1963 land-use reform (Lambton 1969, McLachlan 1988, Majd 2000). By following the traditional methods of rangeland utilization in this region, the pastoralists could maintain sustainable conditions. Therefore Nariyan village was chosen as a case study to show the role that indigenous ecological knowledge is playing in safeguarding adaptive rangeland management under adverse political frame conditions which are hitherto scarcely documented.

Taleghan District is located in the Alborz province of northern Iran and consists of 80 villages located at $36^{\circ} 13$ northern latitude and $50^{\circ} 59$ eastern longitude. Nariyan village is located in the high mountains of the Taleghan region (Fig. 1) at 2360 m elevation and comprises an area of about 5942 ha, which is about $90 \%$ of the Taleghan catchment area. Some of the local population is absent in winter because many men are in the winter grazing lands: the number of households varies from winter to summer, and could be between 90 and 350 .

The communal grazing permit was given to the Village Islamic Council of Nariyan by the District Office of Natural Resources in Taleghan in 1986, which indicates that it took more than 20 years between the promulgation of the Nationalization of Rangelands and Forests Act of 1963 and its implementation in this remote part of the country. This permit allows pastoralists to utilize the rangelands within the traditional boundaries of Saman Orfi (which is a locally well-known geographic area that is recognized traditionally by the villagers, according to customary law, such that in every village pastoralists are entitled to utilize rangelands within this area); it defines the perimeter of the village for grazing livestock. The number of animals that are allowed to graze over a certain period of time is determined by the District Office staff, based on ecological factors such as the amount of forage production accessibility for livestock, rangeland area, daily requirement of the animals, and the grazing period. The grazing capacity indicates the approximate number of livestock that a certain rangeland may sustain over a certain period of time. The district staff estimates the amount of forage production accessibility, through measuring the yield or standing forage crop in one hectare; and then, to ensure 
sustainable conditions, 10 to $60 \%$ of this figure, depending on the rangeland condition, is considered the allowable amount to be harvested by livestock per hectare and per month (Abolhassani 2011).

Fig. 1. Map showing the location of Nariyan village in the province of Alborz in the Taleghan District in northern Iran. The traditional boundary of Nariyan village is shown in red. (Source: M. Ghorbani, H. Azarnivand, A. K. Mehrabi, M. Jarari, H. Nayebi, and K. Seeland, personal communication).

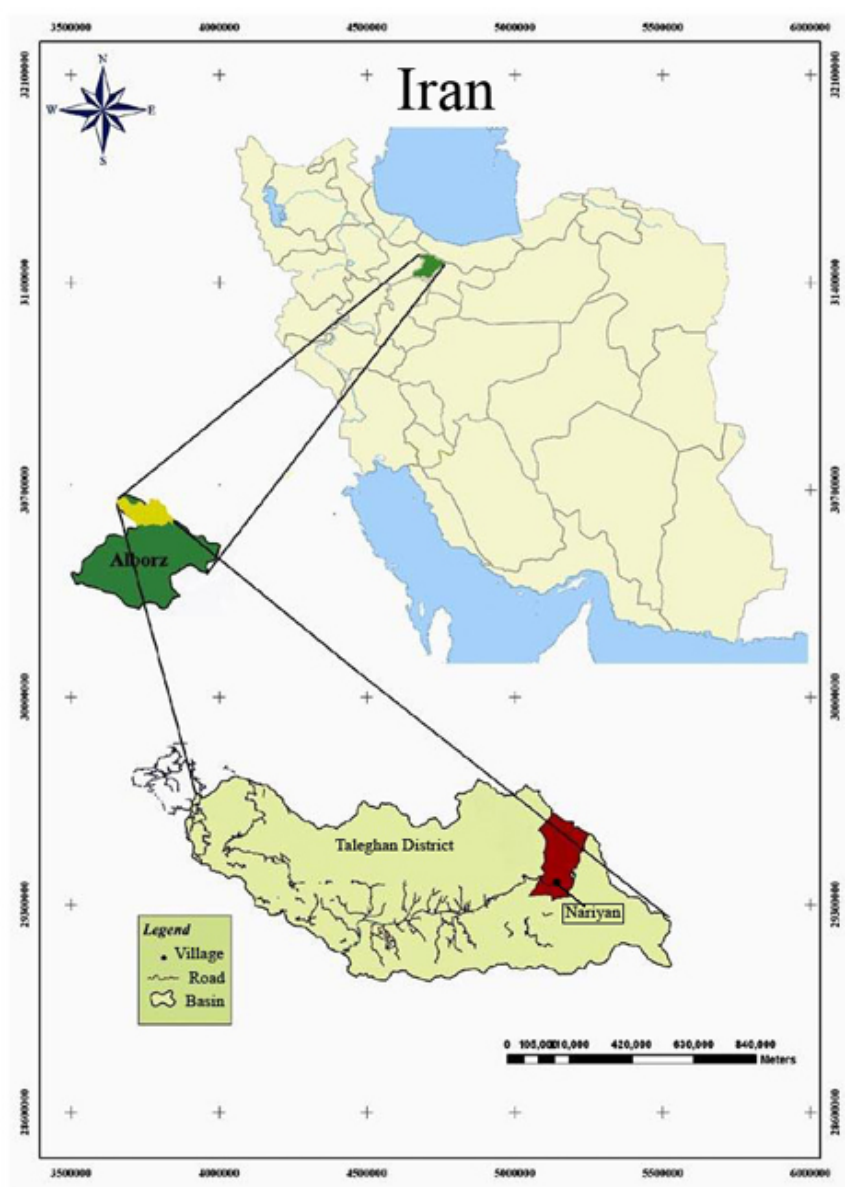

\section{METHODS}

Between 2010 and 2011, we interviewed all of the pastoralists who were managing their own herds $(\mathrm{N}=27$; response rate of $100 \%$ ) and whose ages varied from 40 to 70 years. Because not all village households are pastoralists and only some of them own sheep and goats, in winter only $30 \%$ of the total population are present in the village and in summer only $8 \%$ of the population are present. All pastoralists who stay in the village are engaged in producing dairy products in the summer and in winter they have to feed their animals. We did interviews exclusively with men because they make all decisions concerning their livestock. The questions related to traditional systems of rangeland utilization, ecological knowledge concerning plants and animals, and ecological memory and environmental history. All data were obtained through qualitative and quantitative methods during a 17-months stay in the region. We maintained an ongoing relationship with the pastoralists in order to build up a sense of trust and to be allowed to accompany them with their flocks; we also spent several nights in their mountain camps.

One of our first efforts was to make a map on which the village rangelands (Saman Orfi) are identified, because this document is needed to obtain the grazing permit. But more importantly - and this had not yet been done-was the classification of the rangelands according to the indigenous land assessment categories (Fig. 2). At first, the map of the Saman Orfi was drawn by one of the authors. It was discussed in a participative manner and later on revised according to the land-use records of the local authority. After that, we recorded the subdivisions that had been defined by the pastoralists over a longer period of time. Next, we made a list of all pastoralists and the number of their flocks in Nariyan village, and recorded those herd owners and their flocks that participate in the community herding process where the individual owners' herds are united.

The seasonal grazing management cycle was investigated regarding the respective grazing capacity of the rangelands and the pastoralists' knowledge about determining the beginning of the grazing season according to when the plants were considered mature enough for grazing. We also did basic research on ethnobotany and ethnomedicine applied to animal husbandry, particularly with respect to the palatability of relevant fodder plants. We compared our findings to the pastoralists' knowledge about the plants, particularly in terms of ranking their palatability.

\section{RESULTS}

The stakeholders of each herd congregate in a social network called Chakaneh (one herd) utilizing the common rangelands. Herd management is a very complex and participatory phenomenon. In each herd, the different social roles are all taken by men. There is the Pishkar who is the head of herd, and there is the Rafigh who helps the Pishkar manage the herd during the 9 months grazing season; these people do most of the organizing of the Chakaneh. They organize the building of temporary camps, the provision of drinking water for the herders, the preparation of food, and the care of the transport mules. Supplementary to these roles is the Taraz-who has a few animals and stays in the village and has no role in the management of the herd during the grazing season-who hands over his animals to the Pishkar or one of the Rafighs based on mutual trust. Taraz must pay the costs of taking their animals to the rangelands for grazing, including the wages of 
all persons involved; the fee to lease the rangeland in spring, summer, and autumn seasons; and the vaccination costs for their animals. The shepherd, who just works for the herd owners, plays a minor role in the Chakaneh and is often an outsider or a foreigner. The Pishkar is the responsible person of the herd who governs all affairs related to livestock management, including leasing of the rangeland, finding shepherds, finding solutions for conflicts among the livestock owners, and accounting for the herd expenses. In this study, we focused mainly on the network of participatory activities of the Pishkar and Rafighs, in addition to the pastoralists, all of whom are male and accompany the herd for 9 months. Women are only involved in the dairy production activities, which occur during the spring and summer months and to which we refer in another paper.

Fig. 2. Map of the Saman Orfi (traditional boundary) of Nariyan village. Saman Orfi consists of all the common rangelands and the private rangelands of oulvak. The area of Saman Orfi is about 5942 ha. (Source: M. Ghorbani, H. Azarnivand, A. K. Mehrabi, M. Jarari, H. Nayebi, and K. Seeland, personal communication).

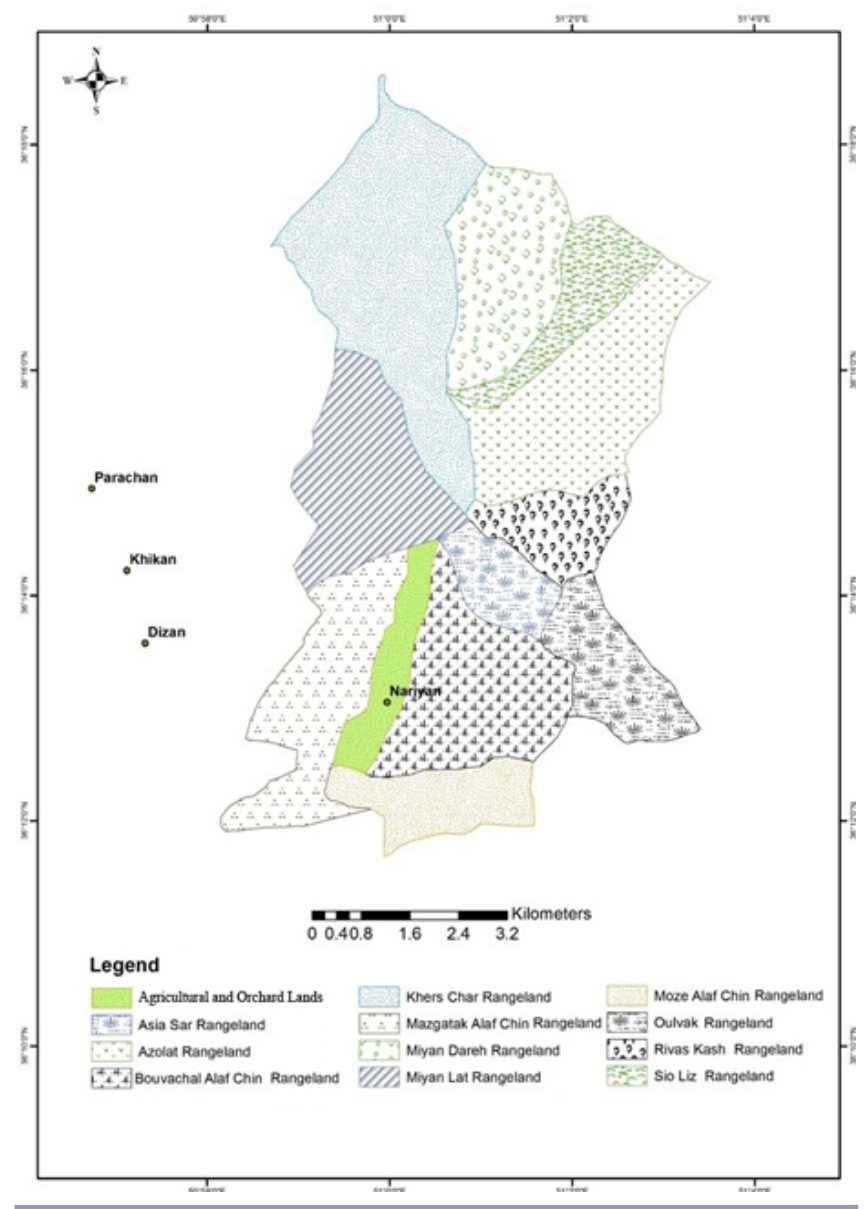

\section{Ecological memory and livestock management}

One of the most striking characteristics of Nariyan pastoralists is their extraordinary memory. In every herd, Pishkar and Rafighs are able to identify the owner of each animal, a skill known as Shenas. This ability is highly valued, especially during the milking periods in spring and summer. In spring, the herd will be led by the shepherds to the Baramal (a fenced area for livestock milking) after coming back from the rangelands. The pastoralists, who are the livestock owners, do not allow the hired shepherds to milk their animals because they cannot identify an animal with its owner.

Several systems of livestock classification and denomination are in place (see Table 1). Markings include the shape and color of different body parts, such as head, horns, and ears, and also whether or not an animal has horns and ears. The pastoralists often make a notch on an animal's ear with scissors called Dooârd, or they burn a sign called a Dershomon the nose of the animal. Sometimes, pastoralists use marking signs, such as natural or industrial color and emblems, to accurately recognize the animals. The industrial colors have better longevity but they are not easy to obtain and also reduce the quality of the wool. Sometimes the pastoralists use henna, a natural color that improves the quality of wool but it does not have the desired longevity.

Table 1. Local names for sheep and goats in Nariyan village, by age and sex.

\begin{tabular}{|c|c|c|}
\hline \multirow[b]{2}{*}{ Age and sex } & \multicolumn{2}{|c|}{ Local names } \\
\hline & Goats & Sheep \\
\hline Birth to 3 months & Khâle Kooli & Khâle Vareh \\
\hline 3 to 6 months & Kooli & Vareh \\
\hline \multicolumn{3}{|l|}{6 months to 1 year } \\
\hline Female & Cheposh female & Togholi female \\
\hline Male & Cheposh Kal & Togholi male \\
\hline \multicolumn{3}{|l|}{1 to 2 years } \\
\hline Female & Kâhâr female & Kâvi female \\
\hline Male & Kâhâr Kal & Kâvi male \\
\hline \multicolumn{3}{|l|}{2 to 6 years } \\
\hline Female & Boz (Deo) & Mish (ewe) \\
\hline Male & $\operatorname{Kal}($ Buck) & Ghooch (Ram) \\
\hline \multicolumn{3}{|l|}{$>6$ years } \\
\hline Female & Pireh Boz & Pireh Mish \\
\hline Male & Kal & Ghooch \\
\hline
\end{tabular}

Owners are rarely mistaken in recognizing their animals, and almost all members of a family have this same ability. If a pastoralist loses one of his animals or his animal merges with another herd, he will, even after one or two years, be able to recognize the lost animal. He would also be able to identify the mother of a small animal and which animal has bred and which one has not. For a pastoralist, having a good memory is of utmost practical and social importance, providing the herd owner with the esteem of his peers. 
Pastoralists' collective memory and local oral history of livestock rearing

In the winter, almost all pastoralists who remain in the village gather each night in the home of one of the members of the Chakaneh social network. This is a long-standing custom and the pastoralists have extensive conversations about natural events, such as flooding, snow avalanches, and other natural calamities that have happened during the last years of their participatory herding. For example, there was a heavy flood in April 2011, and the herd owners lost a lot of livestock in one of the worst events that year. The collective memory that keeps a record of natural hazards has a remarkable impact on the pastoralists because it allows them to compare these events and eventually find indicators to predict these calamities. Pastoralists remember the birth and mortality rates of their small livestock and spend about $80 \%$ of their time on information exchange related to animal and rangeland management.

\section{Ecological knowledge and the utilization of rangelands}

\section{Rangeland division}

Rangeland division is done according to the readiness of rangeland fodder plants and is also influenced by topographic conditions. The pastoralists divide the rangelands into Nesar (behind the sun) and Baraftab (in front of the sun). Nesar is a northward-facing slope; it receives only a little sunlight and therefore has a lower temperature than a southward-facing slope. Baraftab is a southward-facing slope: here plant growth starts earlier because the soil retains more moisture. This area also absorbs more sunlight and snowmelt starts earlier, making the rangeland ready before the Nesar lands can be used.

\section{Adaptive rangeland management strategy and landscape classification}

Pastoralists closely monitor the stages of plant growth, an essential task for maintaining sustainable grazing lands, because releasing flocks onto the land too early will degrade the vegetation cover (Holechek et al. 2000). Following the traditional calendar, on the $30^{\text {th }}$ of March the pastoralists move their livestock to the lowland winter rangelands outside Taleghan, close to the Savojbolagh region, and stay there for about four days. (All dates given are approximate, within a day or two.) If the Pishkar can find a shepherd, then he will accompany the herd after the arrival of the livestock in the lowland rangelands, and take it to the rented rangelands every day. Nariyan pastoralists have to rent lowland rangelands for about two months in a grazing season, because the lowland rangeland located outside the Saman Orfi of Nariyan belongs to another village. The Pishkar rents these rangelands for the entire Chakaneh. At that time, the herd is a mixture of small and adult animals. No milking is done in this 4-day period and the small animals can have all the milk of their mothers. However, when a small animal dies, the pastoralists go on milking the mother to prevent lactation from stopping.
Animals that cannot be milked are called Mijak (dry animals). When the milking season has started, the herds are reunited for one hour after each milking turn so that the small animals can have the remaining milk from their mothers.

There are three herds in Nariyan village and their migration tours are illustrated in Figs. 3, 4, and 5. The herds, which numbered 2433 animals in 2010 to 2011, stay in the lowland rangelands until the $25^{\text {th }}$ of May and are then taken to the rented rangelands of Middle Taleghan (in the administrational classification, Taleghan region is divided into three regions: Upper Taleghan, Middle Taleghan, and Lower Taleghan. Nariyan village is located in Upper Taleghan) region, a trip that takes 4 days for the herds. The livestock grazes here until the $16^{\text {th }}$ of June. These rangelands are called Beyne Rahi and are rented by the Pishkar. One of Beyne Rahi rangelands is called Oulvak, which is a private rangeland belonging to one of the Rafighs among the Nariyan pastoralists, whereas the Saman Orfi lands are commons.

Fig. 3. Herd management in the rangelands during 2011: herd no. 1. (In this herd, the shepherds use the Oulvak rangeland that is located next to Nariyan village (Fig. 2). This rangeland is shown on the map and is under the private ownership of one of Rafighs in this herd. Therefore the members of the herd pay a grazing fee to him when they use the rangeland.)

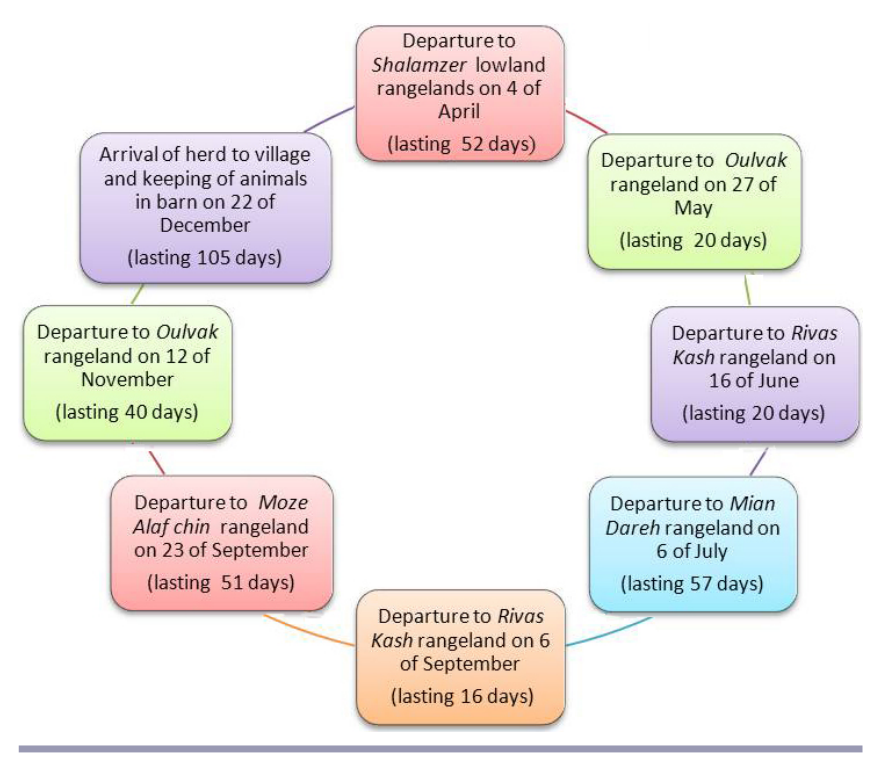

By the $17^{\text {th }}$ or $18^{\text {th }}$ of June, the herds have moved to the rangelands of Saman Orfi, i.e., the customary boundary of Nariyan village. The Saman Orfi consists of several divisions, as shown in Fig. 2. According to the village landscape classification, the rangelands are divided into two parts: nationalized rangelands, and buffer zones of village rangelands or rangelands that are exempt from the 
nationalization law of forests and rangelands of 1963 (a category called Harim). The nationalized rangelands are comprised of the high commons or Sar Kooh (Sar means up and Kooh means mountain) and the middle commons or Paeen Kooh (Paeen means down). The herds stay in the middle rangelands for 15 days from the $22^{\text {nd }}$ of June onward if this area is ready for grazing. The District Office of Natural Resources of Taleghan issues the required grazing permits, which state the allowable number of livestock and also their time of departure and arrival to the rangelands (District Office of Natural Resources Taleghan 2009).

Fig. 4. Herd management in the rangelands during 2011: herd no. 2.

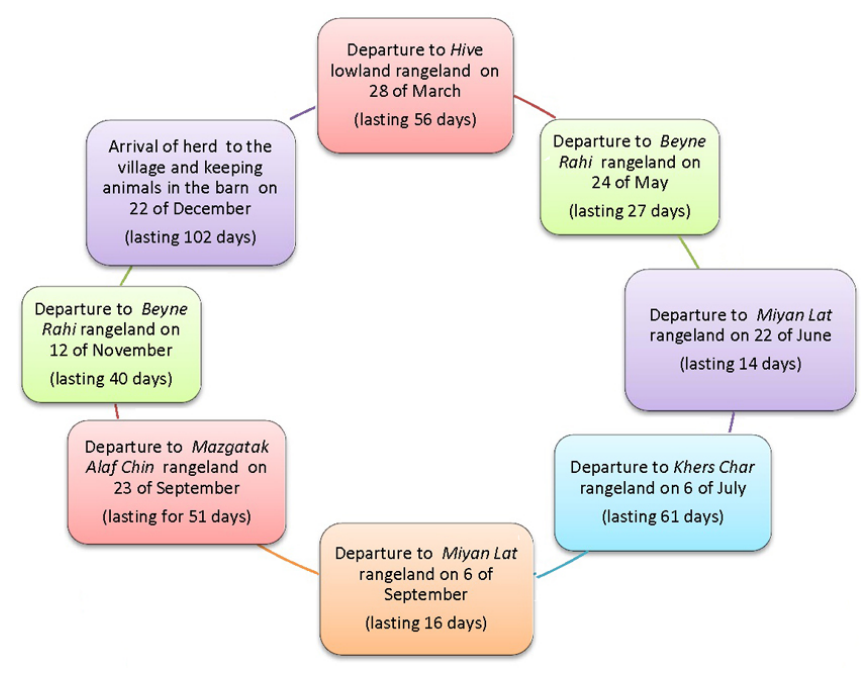

Certain rangelands close to the village, known as the Harim or Alaf Chin (Alaf means forage and Chin means cutting), are allotted by the Islamic Village Council to pastoralists for grazing a limited number of larger animals, such as cows, and for cutting grass to be stored for the winter feeding. The fact that these rangelands are close to the village and are easily accessible makes it hard to avoid overgrazing. In autumn, the herds may stay there for 40 days.

In the high and middle rangelands, an annual rotation system is in place to make sure that all pastoralists have equal access to choice grazing lands. The middle rangelands are much preferred because they are near to the pastoralists' homes and families and feel safer than the more remote areas. The middle rangelands are structured according to topography, type of watershed, and type of ridge, as follows: Asia Sar (Asia means mill and Sar means up), Rivas Kash (Rivas is rangeland covered with Rheum ribes (lat.) which is an edible, perennial, wild species of rhubarb for grazing, and Kash means uneven land), and Miyan Lat (Miyan is rangeland located between two valleys and Lat means that it is close to a river). Every herd uses one of these areas for 15 days/year; each area rotates to another herd in the next year.

Fig. 5. Herd management in the rangelands during 2011: herd no. 3 .

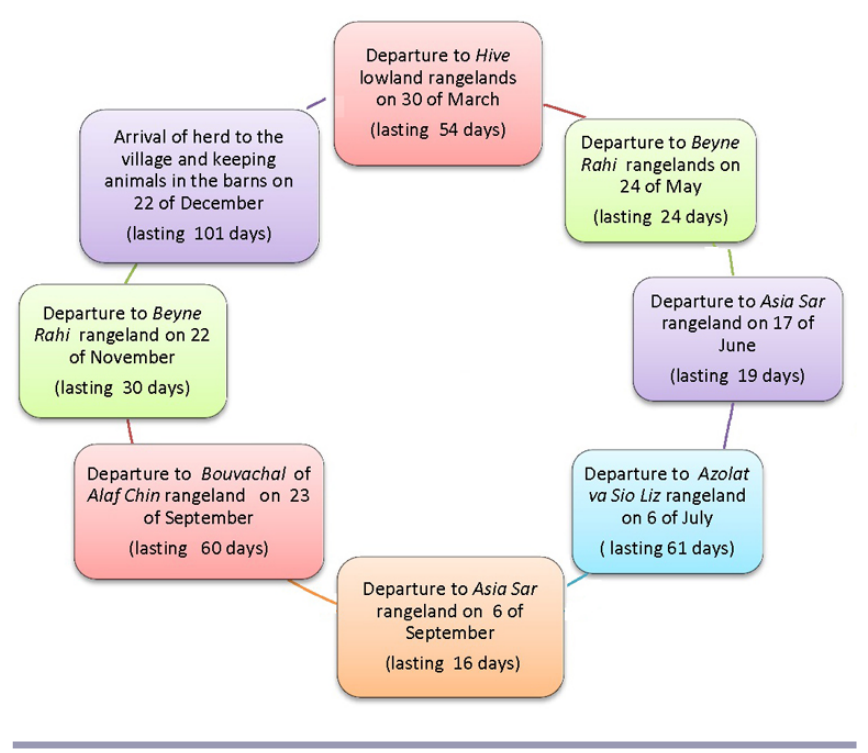

When the temperature is rising and the vegetation is growing well, the herds are taken to the summer high rangelands and small and large livestock are grazed separately. Before the departure to these high summer rangelands, two members of the Chakaneh who are experts in rangeland botany visit the rangelands and assess the situation. They identify useful grazing plants based on their experience by morphological characteristics such as shape and color of flowers, leaves, and fruits, as well as by taste. For instance, they identify Saneh [Centaurea behen] by its wide leaves, Gorz [Diplotaenia cachrydifolia] by its little and green-colored leaves, Kangar [Gundelia tournefortii] by its rough leaves, and Torsh torshak [Rumex sp] by its sour-tasting leaves. Once the rangelands are ready for grazing, every herd is taken to a specific area. According to Figs. 3, 4, and 5 the arrival time in the high rangelands is the same for all herds, i.e., usually the $6^{\text {th }}$ of July. The high rangelands consist of Khers Char (rangeland with many bears that are herbivores), Miyan Dareh (rangeland located between two valleys), Azolat (Azo means lack of water and generally means the rangeland that lacks sufficient water for animals) and Sio Liz (rangeland with a lot of gravel and $\mathrm{Liz}$ means the slope is steep). Azolat and Sio Liz rangelands are grazed by the herd at the same time (Fig. 2).

On the $12^{\text {th }}$ of September, the herds are brought down to the middle rangelands again and stay there for 13 to 16 days. The end of this period coincides with the end of the milking period. After that, the herds arrive at the Alaf Chin rangelands and stay there for approximately one month (October). The small 
and adult animals stay together in a united herd until the end of October because the milking period is over and the animals need to put on weight to be able to survive the harsh winter months. When the livestock is in the middle rangelands, every villager harvests forage from the Alaf Chin and stores it in his house, usually on the second floor of the building, for the winter stable feeding.

In November and until late December, the herds are moved to the Beyne Rahi rangelands of Middle Taleghan region and stay for two months. Small and adult animals continue to graze together here and are accompanied by the shepherds. Sometimes, to decrease costs, just one shepherd takes care of the herd and the other pastoralists help him in rotation.

In January, the herds go back to Nariyan village. Every pastoralist stables his animals and feeds them three times a day. Winter does not mean time off for the pastoralists, because it is the breeding period and regular stable feeding requires plenty of time.

\section{Customary norms of rangeland management and usufruct rights}

The Alaf Chin rangelands in Taleghan consist of Bouva Chal (Bouva means flat and Chal means uneven level), Maz Gatak (Maz means the boundary of Saman Orfi that separates two villages and Gatak means the land covered with Agropyrum sp.), and Moze (rangeland that has the shape of a Crescent; Moze means Banana) (Fig. 2). According to customary law, no pastoralist may use any rangeland before the arrival of all herds to the Saman Orfi. The statement of one of the Pishkars explains this custom, which is respected by all:

This year, before arriving at Nariyan village, the Rafighs requested me to go to the middle rangelands 5 days earlier than the statutory time, because we had a very hard spring in the rangelands, but I did not agree because I believe that we should respect customary law. I think my Rafighs are sulky with me because of my reaction, but I can't do this because the vegetation cover of the middle rangeland isn't ready for grazing and rangeland conservation is my first priority and my livelihood and animals are my second priority. Also I should have logical reasons for the other Pishkars in the other two herds and I believe this will result in irregularity and distrust between pastoralists and perhaps the other pastoralist won't cooperate with us if we would have done this.

Two other customs are also taken quite seriously. Sira Koni (Sira means full nutrition and Koni means doing this action) is one of the most important aspects of the livestock management system and concerns the last night that the livestock are kept in the barn. Pastoralists believe that the animals should be sufficiently fed before they migrate to the lowland rangelands on the following day, to avoid malnourishment. Another custom is Mal Gardani (Mal means animal, and Gardani means the moving of animals in and around the rangeland or village). Before Sira Koni, every pastoralist accompanies his herd just close to the village for a short period of time to ensure the herd is fit for long walking in the seasonal migration cycle. The pastoralists believe that livestock's 2.5-month stay in the barn makes Mal Gardani necessary, otherwise the animals may have difficulties due to the weakness of their hooves.

Application of traditional rangeland management systems: effects on rangeland conditions and future development In Nariyan village, rangeland conditions are reported to be generally good by the local informants and this is confirmed by the respective government offices in charge of assessing rangeland quality. It was disputed by neither the former nor the latter that this can be taken as the result of the pastoralists' in-depth knowledge and traditional rangeland utilization methods. In particular it was mentioned by both that the conditions are mainly due to a respect for the growing cycle of the plants, and the optimal departure and arrival time of the livestock in the rangelands. In rangeland management science, this is known as a delay grazing system.

The results of our research regarding the condition and future development of the rangelands in Taleghan region indicate that the high and middle rangelands are in a good condition (Table 2, District Office of Natural Resources, Taleghan 2009). The rangelands that are next to the village are in good condition in late spring and early summer; the villagers use these places for grazing their cows and also to harvest grass to be stocked for the winter season. In autumn these rangelands may show symptoms of being overharvested by the villagers who use these lands on a first-come-first-served principle, $i$. e., as an open-access resource where they exploit the plant cover ruthlessly until the area looks barren and degraded.

\section{Examples of ecological knowledge about livestock and plants}

The Nariyan pastoralists have a profound knowledge about rangeland plants, including their palatability and medicinal values in preventing and treating human and animal diseases. Table 3 lists some of the salient plants in the rangelands of Taleghan. Pastoralists classify plants according to an index of the animals' preferences for these plants: high, moderate, low, and very low palatability for livestock. Some plants, such as Diplotaenia cachrydifolia, Prangos uloptera DC, and Ferula ovina, become palatable only at the end of July. Before then, the essential properties of the plants and their smell are very strong and the livestock will not graze them. We did not, however, investigate whether this might have something to do with the plants' secondary compounds or metabolites (cf. Papachristou et al. 2007). Some plants are toxic and their 
Table 2. Rangelands in the Saman Orfi of Nariyan village: qualitative classification (District Office of Natural Resources Taleghan 2009).

\begin{tabular}{|c|c|c|c|c|}
\hline Type & Rangeland name & Condition & Trend of condition & $\begin{array}{l}\text { Area } \\
\text { (ha) }\end{array}$ \\
\hline \multirow{4}{*}{$\begin{array}{l}\text { High rangelands } \\
(\text { Sar Kooh) }\end{array}$} & Azolat & Good & Positive & 753.13 \\
\hline & Sio Liz & Good & Positive & 293.32 \\
\hline & Miyan Dareh & Good & Positive & 553.43 \\
\hline & Khers Char & Good & Positive & 1111.60 \\
\hline \multirow{3}{*}{$\begin{array}{l}\text { Middle rangelands } \\
\text { (Paeen Kooh) }\end{array}$} & Asia Sar & Moderate & Positive & 210.60 \\
\hline & Miyan Lat & Moderate & Positive & 611.89 \\
\hline & Rivas Kash & Good & Positive & 264.59 \\
\hline \multirow{3}{*}{$\begin{array}{l}\text { Adjacent common lands } \\
\text { of village } \\
\text { (Alaf Chin) }\end{array}$} & Maz Gatak Alaf Chin & ----- & ----- & 592.68 \\
\hline & Moze Alaf Chin & ----- & ----- & 321.16 \\
\hline & Bouva Chal Alaf Chin & ----- & ----- & 668.75 \\
\hline Private rangelands & Oulvak & Good & Positive & 350.06 \\
\hline $\begin{array}{l}\text { Agricultural and } \\
\text { orchard lands }\end{array}$ & ----- & ----- & ----- & 211.1 \\
\hline Total & ----- & ----- & ----- & 5942.31 \\
\hline
\end{tabular}

palatability is very low in November, such as Sophora alopecuriodes and Euphorbia sp. Other plants are particularly palatable during their growing cycle-especially in spring and summer-such as Bromus tomentellus Boiss., Agropyron trichophorum (Link, Richter), and Melica jacquemontii.

In many ways, the pastoralist functions much as a veterinarian would: for example, a pastoralist's knowledge of plants makes it possible to treat Babezioze (Zardi) [Piroplasmosis] disease (a type of protozoan parasitic febrile disease of cattle, horses, sheep, and swine caused by Babesia ssp). With sheep and goats, this disease is caused by Babesia motasi and Babesia ovis. The parasite grows and multiplies in the blood corpuscles of sheep and goats and causes hemoglobin elimination in the urine. Some signs of this disease are high fever $\left(41.5^{\circ} \mathrm{C}\right)$, difficult breathing, anemia, loss of appetite, and dark reddishbrown urine. Recovered animals may be emaciated and have reduced milk production, and some may also abort (Herenda et al. 1994). This disease is transmitted by mites, which are common among livestock. There is a preventive inoculation; it is not a cure but it has a mitigating effect. In the Taleghan region, veterinarians use vaccines, for instance Diminazone and Emidocarb, to fight this disease. Also, another method for prevention of this disease is to spray various poisons, such as Cyhalthorin and Deltametrina, in the barn and around the animals' resting places during the spring and summer seasons.

One of the Pishkars, Seyed Ghafar Mirghiyasi, explained how he is treating Zardi:
One of the most important abilities of an experienced pastoralist is to diagnose plants to cure animal diseases. It means that he should have enough knowledge about plants and if his livestock is sick, he takes them to the parts of the rangeland that have medical plants. For example, if they have Zardi, he uses the leaves of Lam Rivas [Rheum sp.] to cure it. Several years ago, all livestock in one herd fell ill from Zardi, and 20 to 28 lambs were dying every day. Then the veterinarian visited them and prescribed some drug for them, but it wasn't effective.

When I visited, I told the pastoralists that they should take the herd to the areas that are covered with Rheum $\mathrm{sp}$. The pastoralists accepted my recommendation and after one day all the livestock was healthy without using any kind of chemical drugs. Therefore, the basic way to cure livestock diseases is through medical plants, not chemical drugs. A similar case happened to my herd and I told the shepherds to take the herd to the parts of the rangelands where the Lam Rivas plant grows, which was effective. I believe this plant is actually able to drain the digestion system of livestock.

One of the experienced shepherds believes that the main reason for this disease is Zorbeh (Thymus kotschyanus), which gives the livestock a lot of energy. After a long grazing period in the rangeland, when the herd has finished with the available 
Table 3. Some rangeland plants in the Saman Orfi of Nariyan village: pastoralists' assessment of palatability for livestock.

\begin{tabular}{|c|c|c|}
\hline Plant name & Palatability & Characteristics \\
\hline $\begin{array}{l}\text { Gorz } \\
{[\text { Diplotaenia cachrydifolia }]}\end{array}$ & Good in the late July & $\begin{array}{l}\text { In late July it is palatable for sheep and lambs because it has lost its } \\
\text { bitterness. If livestock eat it a lot, the color of their wool will } \\
\text { change to red. Also, because of its bitter smell, it may result in } \\
\text { dyspepsia in the shepherds. Shepherds should use yoghurt and } \\
\text { Halva to cure it. This plant is also used in winter for livestock } \\
\text { feeding. }\end{array}$ \\
\hline $\begin{array}{l}\text { Speres } \\
\text { [Onobrychis Cornuta (L.) Desv.] }\end{array}$ & Good & A palatable plant that increases the amount of milk of livestock. \\
\hline $\begin{array}{l}\text { Bur Ghiyagh } \\
\text { [Agropyron sp.] }\end{array}$ & Good & A good palatable plant for several kinds of livestock. \\
\hline $\begin{array}{l}\text { Saju } \\
\text { [Scariola Oreintalis (Boiss.) Sojuk. ] }\end{array}$ & Moderate & A moderate palatable plant that is also used for making brooms. \\
\hline $\begin{array}{l}\text { Taraz } \\
{[\text { Achillea talagonica Boiss)] }}\end{array}$ & Moderate & $\begin{array}{l}\text { It has moderate palatability and is useful for several kinds of } \\
\text { livestock. }\end{array}$ \\
\hline $\begin{array}{l}\text { Alho } \\
\text { [Prangos uloptera DC.] }\end{array}$ & Good in the end of July & Like Gorz, livestock eat the dried leaves in the end of July. \\
\hline $\begin{array}{l}\text { Komah } \\
\text { [Ferula ovina] }\end{array}$ & Good in the end of July & Similar to Gorz and Alho. \\
\hline $\begin{array}{l}\text { Gavan } \\
\text { [Astraglus aureus Wills.] }\end{array}$ & Moderate for goat & $\begin{array}{l}\text { A moderately palatable plant for goats, but because of its thorns is } \\
\text { not favorable for sheep. }\end{array}$ \\
\hline $\begin{array}{l}\text { Kerak } \\
\text { [Bromus tomentellus Boiss.] }\end{array}$ & Good & A very palatable plant for several kinds of livestock. \\
\hline $\begin{array}{l}\text { Jarand } \\
\text { [Ferula persica] }\end{array}$ & Moderate & $\begin{array}{l}\text { A moderately palatable plant; somewhat bitter; used by sheep } \\
\text { during early stages of plant growth. Villagers use it for soup as } \\
\text { well as a treatment for diabetes. }\end{array}$ \\
\hline $\begin{array}{l}\text { Kangar } \\
{[\text { Gundelia tournefortii] }}\end{array}$ & Moderate & Its dried leaves are moderately palatable for livestock. \\
\hline $\begin{array}{l}\text { Chay Chupan } \\
\text { [Stachys lavandulifolia vahl.] }\end{array}$ & Moderate & $\begin{array}{l}\text { A moderately palatable plant for livestock; shepherds also use it } \\
\text { for tea. }\end{array}$ \\
\hline $\begin{array}{l}\text { Torsh torshak } \\
\text { [Rumex } \mathrm{sp}]\end{array}$ & Moderate & $\begin{array}{l}\text { It has very small leaves and is palatable to livestock and humans. It } \\
\text { has sour leaves. }\end{array}$ \\
\hline $\begin{array}{l}\text { Yunje } \\
{[\text { Medicago sativa }]}\end{array}$ & Good & A very palatable plant for several kinds of livestock. \\
\hline $\begin{array}{l}\text { Avishan (Zorbeh) } \\
\text { [Thymus kotschyanus Boiss and } \\
\text { Hohen }]\end{array}$ & Poor & $\begin{array}{l}\text { Has poor palatability and is commonly used for medical purposes, } \\
\text { especially for digestive diseases. }\end{array}$ \\
\hline $\begin{array}{l}\text { Shir var } \\
\text { [Agropyron trichophorume (Link) } \\
\text { Richter.] }\end{array}$ & Good & A very palatable plant for several kinds of livestock. \\
\hline $\begin{array}{l}\text { Rivas } \\
\text { [Rheum ribes] }\end{array}$ & Good & $\begin{array}{l}\text { Its leaves are used by livestock. It is also an economic plant for } \\
\text { rural families. } 1 \mathrm{~kg} \text { costs US } \$ 1 .\end{array}$ \\
\hline $\begin{array}{l}\text { Menna } \\
\text { [Eryngium bungei] }\end{array}$ & Good & $\begin{array}{l}\text { A very palatable plant for sheep and goats; the stems are useable } \\
\text { for human consumption. }\end{array}$ \\
\hline $\begin{array}{l}\text { Varak } \\
\text { [Hultemia persica] }\end{array}$ & Moderate & $\begin{array}{l}\text { A vary palatable plant with yellow flowers. When the flower of } \\
\text { this plant appears, pastoralists leave the lowlands because if } \\
\text { livestock graze it in this state they will come down with Babezioze } \\
\text { disease. }\end{array}$ \\
\hline $\begin{array}{l}\text { Boz Kangar } \\
\text { [Gundelia sp] }\end{array}$ & Good, for goat & A very palatable plant for goats. \\
\hline $\begin{array}{l}\text { Azragh Kangar } \\
\text { [Gundelia sp] }\end{array}$ & Poor, for sheep & A poorly palatable plant for sheep; mules eat it in winter. \\
\hline
\end{tabular}




\begin{tabular}{|c|c|}
\hline Ab Kangar & Poor, for sl \\
\hline $\begin{array}{l}\text { [Gundelia sp] } \\
\text { Vayeh }\end{array}$ & Good \\
\hline $\begin{array}{l}\text { [Melica jacquemontii] } \\
\text { Saneh }\end{array}$ & Good, in w \\
\hline [Centaurea behen] & \\
\hline $\begin{array}{l}\text { Khames } \\
\text { [Vicia sp] }\end{array}$ & Moderate \\
\hline $\begin{array}{l}\text { Taleh } \\
\text { [Sophora alopecuriodes] }\end{array}$ & Very poor \\
\hline $\begin{array}{l}\text { Marzeh } \\
\text { [Scutellaria pinnatifida] }\end{array}$ & Moderate \\
\hline $\begin{array}{l}\text { Shirin Bayan } \\
\text { [Glycyrrhiza glabra] }\end{array}$ & Good \\
\hline $\begin{array}{l}\text { Sineh panj } \\
\text { [Euphorbia sp] }\end{array}$ & Very poor \\
\hline
\end{tabular}

palatable plants, they will feed on Zorbeh and get fever, and Babezioze that may be cured by Rheum sp. and Rumex sp. Moreover, pastoralists believe that by changing the grazing area, and by conducting burning in the rangeland after the completion of grazing and thus destroying Zorbeh, may be helpful in the prevention of the Babezioze disease.

One of the predominant plants in Taleghan and adjacent regions is Gorz (Diplotaenia cachrydifolia). When the leaves of this plant are green, the livestock will not eat it, but after about the 22 of July the leaves are usually dry enough. Gorz will substantially increase the amount of milk the livestock produce, but excessive consumption will make the livestock thirsty.

Recognizing the right time to water the livestock is an important aspect of ranching and requires much planning because there are very few water reservoirs in the rangelands. A common conviction among local pastoralists holds that if the shepherd takes the herd to the water reservoir at the right time, i.e., in the early hours of sunrise or sunset (when one side of the mountain is covered by sunlight and on the other side there is shade) the livestock will drink more water. Another common belief is that the best time to give water is after grazing. Pastoralists also hold firm to their traditional grazing timetable by saying: "Every plant has a distinct suitable time for grazing. The shepherds should not conduct herds to the rangelands until this time comes; like marriage has its suitable time and until it comes, people usually don't marry”.

Nariyan pastoralists pay close attention to how livestock move across the rangelands, because use of the wrong approaches is one of the most significant causes of lost vegetation cover and soil degradation. The pastoralists told us that a shepherd should move the herd slowly in a sloping way to the mountain flanks and the herd should move horizontally and not vertically
A hydrophytes plant; sheep do not often use it.

A very palatable plant for all kinds of livestock.

A hydrophytes plant with a good palatability. It has wide leaves and is used as livestock feed in winter. Shepherds use it to cover their faces in summer.

A moderately palatable plant for livestock. It has seeds that are like peas and which villagers are fond of when ripe.

This is a toxic plant and livestock graze on it only in November when nothing else is available.

A moderately palatable plant for livestock in the beginning of August.

A plant that is palatable to all kinds of livestock.

This is a toxic plant and its palatability is very poor for livestock; animals graze it only in November. in order to prevent plant roots from becoming exposed and soil from degrading.

Nariyan pastoralists rely on traditional astronomical signs to determine the time for grazing. One such example is called Halakar, a sign of midnight. By this time, the herd should have grazed for 2 to 3 hours, which is a period known as Shab Char, and which leads to an increase in the amount of milk produced. After Shab Char, the livestock rests in a place called Gahereh, which is the residence of the herd. They also believe that from 4 to 5 a.m., when the Sepidi star appears, the livestock should not move but stay and ruminate and digest the forage which is thus transformed to milk, body mass, and energy, because to do otherwise would cause a decrease in the amount of milk.

\section{Indigenous knowledge of herd management}

Pastoralists use several methods to hold their herds together. The animals are trained to listen and react to particular words and sounds. These sounds guide and direct them to the water or grazing ground, or they may forbid movements. A bell is usually tied to a buck $(\mathrm{kal})$, because the pastoralists believe that the kal is intelligent and reacts very quickly in case of danger, alerting the shepherd's dog to combat the danger. The sound of the kal's bell indicates the speed of the herd's movement to all of the animals and prevents the shepherd from falling asleep. One pastoralist told us “ . . . that experienced thieves will first silence the sound of dogs and the livestock's bells". Some pastoralists believe that old, experienced livestock help keep the herd together because they are used to moving in groups and show courage by encircling young livestock in case of danger. A pastoralist said:

Livestock won't sleep until they find suitable and desirable places for resting. A desirable place is at a higher level than the surrounding area and the site opposite of this resting place should have the shape of a crescent. The livestock prefer these places to 
have a full view of the surrounding area. After staying in this selected place, the livestock guards itself and if it feels any danger, they warn the other livestock and the shepherd and his dog by making noise.

\section{Herd composition and livestock distribution ratios}

The pastoralists of Nariyan intentionally build up herds in a clever way, comprising them of both goats and sheep. They try to include certain combinations of does and ewes in the herd in order to effectively manage the herd's overall grazing habits (Vallentine 2001). According to one pastoralist, it is important to include goats in a herd for the following reasons:

Goats prevent inactivity of the herd and ewes prevent too much activity of the herd. Goats guide the herd and if there are no goats it will make the herd stay in a place in cold weather, but goats even in cold weather can find forage and guide the herd towards it. Goats are good climbers in mountainous and difficult regions and can graze steep slopes. Goats graze shrubs in drought years and even in poor rangelands, nevertheless they survive and give milk. But lambs are less active and more delicate than goats and need fresh and sufficient fodder in the rangelands.

The herd's composition and diversity makes it possible for the animals to graze on several species of plants at the same time, which decreases pressure on the palatable plants in one area and also prevents the extinction of unpalatable species.

Another way to control livestock distribution in the rangelands is by locating salt blocks (Liseh) at certain places and building stock ponds. These measures contribute to a more even distribution of livestock across the rangelands, which helps to prevent soil compaction; soil compaction can decrease the capacity of the soil to absorb water and lead to soil erosion (Holechek et al. 2000).

\section{Estimation of rangeland grazing capacity based on pastoralists' indigenous knowledge}

Maintaining the right rangeland-livestock ratio is one of the basic principles of range management because an excessive number of livestock in the rangeland will cause its degradation in the long run. One of the pastoralists spoke about the estimation of grazing capacity of their rangelands in the past and today: "For hundreds of years, our fathers had estimated the grazing capacity of several rangelands of Nariyan and we have inherited this experience”. (Grazing capacity in the grazing permit is based on the high rangeland data, because the livestock stay for a longer time in the high rangelands during summer so the protection of the high rangelands is important for the District Office of Natural Resources of Taleghan. Livestock stay in the middle rangeland for a short time only and therefore the grazing capacity of the rangeland is not defined.)

The rangelands are divided into traditional Iranian units called Charaks; a Charak is equivalent to 90 ha. The sum area of the high and middle rangelands of Nariyan is 43 Charaks, which is equal to 3870 ha (Table 4). The grazing permit issued by the Taleghan District Office of Natural Resources, which is based on scientific methods of calculation of forage production, size of the rangeland area, and duration of the grazing period, is for $\sim 3800$ ha, which is just 70 ha less. This shows that traditional and modern scientific methods lead to calculating a very similar animal-forage growth with a similar ratio, although the District Office of Natural Resources allows for a slightly higher density of grazing per land unit.

Table 4. Estimated grazing capacity of rangelands inside the customary boundary of Nariyan village, according to indigenous ecological knowledge.

\begin{tabular}{lccc}
\hline \hline Rangeland name & $\begin{array}{c}\text { Area } \\
(\text { Charak })\end{array}$ & $\begin{array}{c}\text { Area } \\
\text { (ha) }\end{array}$ & $\begin{array}{c}\text { Grazing capacity, } \\
\text { according to } \\
\text { indigenous } \\
\text { knowledge } \\
\text { (no. of animals) }\end{array}$ \\
\hline Azolat & & & \\
Sio Liz & 9 & 810 & 990 \\
Miyan Dareh & 3 & 270 & 330 \\
Khers Char & 7.5 & 675 & 825 \\
Asia Sar & 12 & 1080 & 1320 \\
Miyan Lat & 2.5 & 225 & ---- \\
Rivas Kash & 6 & 540 & ---- \\
Total & 3 & 270 & ---- \\
\hline
\end{tabular}

${ }^{\dagger}$ As mentioned before, with regard to the limited stay of livestock in the mid rangelands for 15 days, the grazing capacity of the rangelands is measured based on data for the high rangelands because they play a key role in forage production in summer.

The total grazing capacity of the high rangelands, according to the indigenous ecological knowledge estimation, allow 3465 animals to graze (Table 4 ) but the pastoralists have held the current number to only 2430 animals. Because this number is lower than the rangeland's capacity, no degradation by overgrazing is likely. The official grazing permit from the Taleghan District Office allows 3535 animals to be grazed in the rangelands, which nearly matches the grazing capacity estimated by the herders.

According to the indigenous ecological knowledge of pastoralists, an estimation of the grazing capacity of Nariyan's high rangelands is 31.5 Charaks (2835 ha). Based on experience, in every Charak 110 animals can be grazed 
without endangering the quality of the rangeland. A Charak equals $90 \mathrm{ha}$. If the rangeland is in a good condition, the number of animals that can graze in a Charak is 1.22 animals/ha, based on the pastoralists' experiences.

\section{DISCUSSION}

Indigenous ecological knowledge plays a crucial role at the local level regarding the sustainable use of natural resources in the context of animal husbandry. As shown in this case study, the ecological knowledge of pastoralists has so far maintained sustainable rangeland management in this region through adaptive rangeland management strategies; landscape classification; knowledge of plant-animal interactions, plant characteristics, and palatability of plants; treatment of animals with plants; herd conservation and composition methods; and estimation of grazing capacity.

The traditional methods of estimating the grazing capacity based on the assessment of the vegetation condition and rangeland classification reflects the pastoralists' familiarity with their environment (Fernandez-Gimenez 2000, Oba et al. 2000, Oba and Kotile 2001, Mapinduzi et al. 2003, Sheuyange et al. 2005). Their ecological knowledge of the plants' palatability and their estimation of the pastures' grazing capacity reflect cultural values; and their personal experiences make it possible to minimize land degradation and make optimal use of their livestock and the products they provide.

The animals' movements and the fluctuating use of various grazing areas are steered by the availability of the fodder and medicinal plants. Thus the seasons, as representations of time and drivers in this transhumant system, are essential for the pastoralists to maintain a sustainable livelihood. Guiding the herds to particular pastures by directing them with the help of shepherd dogs and through purposive positioning of salt licks in the grazing land are the only forms of interference with the natural seasonal process of transhumance.

The environmental conditions and the socio-cultural responses to them fulfill the demands of this livelihood system and make for an intricately woven fabric of this unique ensemble of nature and culture (Seeland 1997). Persistence in maintaining the tradition of renewable resource management is imperative to making a sustainable living even when the socio-political conditions are not favoring it, as was the case in Taleghan following the land-use reform of 1963. In resource-use regimes that are managed under conditions of scarcity, with a very limited labor force, indigenous environmental knowledge becomes the key resource of sustainability. Berkes et al. (2000) characterize indigenous ecological knowledge as a "library of information" that can be used to overcome the challenges related to dynamic changes in complex ecosystems. Ingold (2011) and Ingold and Kurttila (2000) have made valuable contributions in this context by approaching the traditional ecological knowledge (TEK) of pastoralists through the perceived environment in boreal cultures. Various examples on the use of traditional ecological knowledge as a means of adaptation under changing climatic conditions are provided by Nakashima et al. (2012) who relate it to contemporary challenges of global warming. Complementary analyses of Fourth World pastoralists and nomadic peoples of the Arctic and subarctic circle have been compiled by Forbes et al. (2009) and Beach and Stammler (2006) who particularly analyze the indigenous ecological knowledge of the human-animal relationship in the context of traditional livelihoods. We have in another paper (Ghorbani et al. 2013) based on empirical research in the same geographical setting analyzed complementary societal forms of cooperation to the Chakaneh system of united herds-such as the Shirvâreh or Vârah. The Shirvâreh system is an institution of mutual help by means of reciprocal milk sharing during the summer milking period. It enables small-scale herd owners to produce cheese and other dairy products that require a critical mass by taking milk from more well-to-do herd owners who possess more animals and giving it back to them later on. The above-mentioned examples of pastoralists' indigenous ecological knowledge, as well as our own, are inspired by acknowledging the soundness of manenvironment interactions that are proven by the persistence of widespread, self-sustaining, rural subsistence economies.

\section{CONCLUSION}

The use of indigenous ecological knowledge in rangeland management in the Taleghan region shows a remarkable continuity. Pastoralists today rely on their own indigenous ecological knowledge in organizing their herd management, treating animal diseases, and assessing the fodder capacity of their grazing lands. It is obviously a successful way of coexisting with the modernization of the government land management rationale which is represented by the District Office of Natural Resources in Taleghan. Despite a rapid societal change in northern Iran due to the modernization of lifestyles and consumption patterns that have swept into remote rural areas, and despite having a rather close proximity to the capital Tehran, an age-old form of transhumance among a pastoralist community has shown vitality and persistence against the changes in land-use policy, by keeping indigenous institutions such as Chakaneh alive.

With neither outside assistance nor support from government subsidies, the Nariyan pastoralist tradition has, according to what informants reported in informal interviews, survived almost unchanged for centuries. Livestock rearing, based on intricate traditional knowledge and practice of grazing land economy, seems to have been a showcase-like precedent of the sustainability concept long before the latter became a key term in environmental sciences and policy. Its economic viability is thus beyond doubt and its social foundation, a prerequisite, has maintained the virtues of cooperation in livestock rearing on a basis of reciprocity and mutual cooperation and without altering the social hierarchies among 
herd managers. Rangeland management in the Taleghan region is an example where an adequate contribution to a local subsistence economy from transhumance can be realized without violating the fodder-providing capacity of the grazing land.

Responses to this article can be read online at: http://www.ecologyandsociety.org/issues/responses. php/5414

\section{LITERATURE CITED}

Abolhassani, L. 2011. Rangeland management in Iran, a socio-economic analysis and case study of Semnan rangelands. PhD thesis. Freiburg University, Freiburg im Breisgau, Germany.

Allsopp, N., C. Laurent, L. M. C. Debeaudoin, and M. I. Samuels. 2007. Environmental perceptions and practices of livestock keepers on the Namaqualand Commons challenge conventional rangeland management. Journal of Arid Environments 70:740-754. http://dx.doi.org/10.1016/j. jaridenv.2006.11.005

Badripour, H., N. Eskandari, and S. A. Rezaei. 2006. Rangelands of Iran, an overview. Ministry of Jihad-eAgriculture, Forest, Range and Watershed Management Organization, Technical Office of Rangeland, Teheran, Iran.

Beach, H., and F. Stammler. 2006. Human-animal relations in pastoralism. In: Humans and Reindeer on the Move. F. Stammler and H. Beach, editors. Theme issue. Nomadic Peoples 10(2):6-30.

Berkes, F., J. Colding, and C. Folke. 2000. Rediscovery of traditional ecological knowledge as adaptive management. Journal of Ecological Applications 10, 1251-62. http://dx.doi. org/10.1890/1051-0761(2000)010[1251:ROTEKA]2.0.CO;2

Bollig, M., and A. Schulte. 1999. Environmental change and pastoral perceptions: degradation and indigenous knowledge in two African pastoral communities. Journal of Human Ecology 27, 493-514. http://dx.doi.org/10.1023/A:1018783725398

Brown, L. H. 1971. The biology of pastoral man as a factor in conservation. Biology Conservation 3, 93-100. http://dx.doi. org/10.1016/0006-3207(71)90007-3

Cotton, C. M. 1996. Ethnobotany: principles and applications. John Wiley \& Sons, Chichester, West Sussex, UK.

District Office of Natural Resources Taleghan. 2009. The report of rangelands inventory and assessment of Taleghan region. Taleghan County, Alborz Province, Iran.
Fernandez-Gimenez, M. 2000. The role of Mongolian nomadic pastoralists' ecological knowledge in rangeland management. Journal of Ecological Applications 10:13181326. http://dx.doi.org/10.1890/1051-0761(2000)010[1318: TROMNP]2.0.CO:2

Forbes, B. C., F. Stammler, T. Kumpula, N. Meschtyb, A. Pajunen, and E. Kaarlejärvi. 2009. High resilience in the Yamal-Nenets social-ecological system, West Siberian Arctic, Russia. Proceedings of the National Academy of Sciences 106:22041-22048. http://dx.doi.org/10.1073/ pnas.0908286106

Fratkin, E. 1997. Pastoralism: governance and development issues. Annual Reviews in Anthropology 26:235-261. http:// dx.doi.org/10.1146/annurev.anthro.26.1.235

Galaty, J., and D. L. Johnson. 1990. The world of pastoralism. Guilford, New York, USA.

Gemedo-Dalle, I. Johannes, and L. M. Brigitte. 2006. Indigenous ecological knowledge of Borana pastoralists in southern Ethiopia and current challenges. International Journal of Sustainable Development \& World Ecology 13 (2):113-130. http://dx.doi.org/10.1080/13504500609469666

Ghorbani, M., H. Azarnivand, A. A. Mehrabi, S. Bastani, M. Jafari, and K. Seeland. 2013. Local traditions of the dairy production chain as a form of indigenous knowledge in the Taleghan region of Northern Iran. Ecology and Society xx(yy): ZZ. [online] URL: http://www.ecologyandsociety.org/ volXX/issYY/artZZ.

Herenda, D., P. G. Chambers, A. Ettriqui, P. Seneviratna, and T. J. P. da Silva. 1994. Manual on meat inspection for developing countries, FAO, Rome, Italy.

Holechek, J. L., R. D. Pieper, and C. H. Herbel. 2000. Range management, principles and practices. Prentice Hall, Englewood Cliffs, New Jersey, USA.

Homewood, K., and W. A. Rodgers. 1989. Pastoralism, conservation and the overgrazing controversy. Pages 111-128 in D. Anderson and R. Grove, editors. Conservation in Africa: people, policies, and practice. Cambridge University Press, Cambridge, UK. http://dx.doi.org/10.1017/CBO9780511565335.009

Homewood, K. M., and W. A. Rodgers. 1991. Maasailand ecology, pastoralist development and wildlife conservation in Ngorongoro, Tanzania. Cambridge, UK. http://dx.doi. org/10.1017/CBO9780511525568

Ingold T. 2011. The perception of the environment: essays in livelihood, dwelling and skill. Second edition. Routledge, London, UK. 
Ingold T., and T. Kurttila. 2000. Perceiving the environment in Finnish Lapland. Body and Society 6:183-196. http://dx.doi. org/10.1177/1357034X00006003010

Knapp, C. N., and M. Fernandez-Gimenez. 2008. Knowing the land: a review of local knowledge revealed in ranch memoirs. Journal of Rangeland Ecology and Management 61:148-155. http://dx.doi.org/10.2111/07-088.1

Lambton, A. K. S. 1969. The Persian land reform. Clarendon Press, Oxford, UK. http://dx.doi.org/10.1080/03068376908732081

Majd, M. G. 2000. Resistance to the Shah: landowners and Ulema in Iran. University Press of Florida, Gainesville, Florida, USA.

Mapinduzi, A. L., G. Oba, R. B. Weladji, and J.E. Colman. 2003. Use of indigenous ecological knowledge of the Maasai pastoralists for assessing rangeland biodiversity in Tanzania. African Journal of Ecology 41:329-336. http://dx.doi. org/10.1111/j.1365-2028.2003.00479.x

McLachlan, K. 1988. The neglected garden: the politics and ecology of agriculture in Iran. I. B. Tauris \& Co. Publishers, London, UK.

Mills, D., R. Blech, B. Gillam, M. Martin, G. Fithardinge, J. Davies, S. Campbell, and L. Woodhams. 2002. Rangelands: people, perceptions and perspectives. Pages 43-54 in A. C. Grice and K. C. Hodgkinson, editors. Global rangelands: progress and prospects. $\mathrm{CAB}$ International, Wallingford, Oxfordshire, UK.

Muller, B., A. Linstadter, K. Frank, M. Bollig, and C. Wissel. 2007. Learning from local knowledge: modeling the pastoralnomadic range management of the Himba, Namibia. Ecological Applications 17:1857-1875. http://dx.doi. org/10.1890/06-1193.1

Mysterud, A. 2006. The concept of overgrazing and its role in management of large herbivores. Wildlife Biology 12:129-141. http://dx.doi.org/10.2981/0909-6396(2006)12[129:TCOOAI] 2.0.CO;2

Nakashima, D. J., K. Galloway McLean, H. D. Thulstrup, A. Ramos Castillo, and J. Rubis. 2012. Weathering uncertainty: traditional knowledge for climate change assessment and adaptation. UNESCO, Paris, France, and United Nations University, Darwin, Australia.

Niamir-Fuller, M. 1995. Indigenous systems of natural resource management among pastoralists of arid and semiarid Africa. Pages 245-257 in D. M. Warren, L. J. Slikkerveer, and D. Brokensha, editors. The cultural dimension of development. Intermediate Technology Publications, London, UK.

Nyerges, A. E. 1982. Pastoralists, flocks and vegetation: processes of co-adaptation. Pages 217-247 in B. Spooner, and
H. S. Mann, editors. Desertification and development: dryland ecology in social perspective. Academic Press, London, UK.

Oba, G., and L. M. Kaitira. 2006. Herder knowledge of landscape assessments in Arid rangelands in northern Tanzania. Journal of Arid Environments 66:168-186. http:// dx.doi.org/10.1016/j.jaridenv.2005.10.020

Oba, G., and D.G. Kotile. 2001. Assessment of landscape level degradation in southern Ethiopia: pastoralists versus ecologists. Land Degradation \& Development 12:461-475. http://dx.doi.org/10.1002/ldr.463

Oba, G., E. Post, P. O. Syvertsen, and N. C. Stenseth. 2000. Bush cover and range condition assessments in relation to landscape and grazing in southern Ethiopia. Landscape Ecology 15:535-546. http://dx.doi.org/10.1023/A:1008106625096

Papachristou, T. G., L. E. Deziba, J. J. Villalba, and F. D. Provenza. 2007. Patterns of diet mixing by sheep offered foods varying in nutrients and plant secondary compounds. Applied Animal Behaviour Science 108:68-80. http://dx.doi. org/10.1016/j.applanim.2006.11.015

Roba, H. G., and G. Oba. 2009. Community participatory landscape classification and biodiversity assessment and monitoring of grazing lands in northern Kenya. Journal of Environmental Management 90(2):673-682. http://dx.doi. org/10.1016/j.jenvman.2007.12.017

Seeland, K. 1997. Indigenous knowledge of trees and forests in non-European societies. Pages 101-112 in K. Seeland, editor. Nature is culture: indigenous knowledge and sociocultural aspects of trees and forests in non-European cultures. Intermediate Technology Publications, London, UK.

Seeland, K. 2000. What is indigenous knowledge and why does it matter today? Pages 11-31 in K. Seeland, and F. Schmithüsen, editors, Man in the forest: local knowledge and sustainable management of forests and natural resources in tribal communities in India. D. K. Printworld (P) Ltd. New Delhi, India.

Seeland, K., and F. Schmithüsen. 2000. The meaning of indigenous knowledge in the use and management of renewable natural resources. K. Pages 1-10 in K. Seeland, and F. Schmithüsen, editors, Man in the forest: local knowledge and sustainable management of forests and natural resources in tribal communities in India. D. K. Printworld (P) Ltd. New Delhi, India.

Sheuyange, A., G. Oba, and R. W. Weladji. 2005. Effects of anthropogenic fire history on Savanna vegetation in northeastern Namibia. Journal of Environmental Management 75:189-198. http://dx.doi.org/10.1016/j.jenvman.2004.11.004

Spencer, P. 2004. Keeping tradition in good repair: the evolution of indigenous knowledge and the dilemma of development among pastoralists. Pages 202-218 in A. Bicker, 
P. Sillitoe, and J. Pottier, editors. Development and local knowledge: new approaches to issues in natural resources management, conservation, and agriculture. Routledge, London, UK.

Spooner, B. 1973. The cultural ecology of pastoral nomads. Addison-Wesley Module in Anthropology No. 45. AddisonWesley Publishing Company, Reading, Massachusetts, USA.

Spooner, B. 1982. Rethinking desertification: the social dimension. Pages 1-24 in B. Spooner, and H. S. Mann, editors. Desertification and development: dryland ecology in social perspective. Academic Press, London, UK.

Sunderland, E. 1968. Pastoralism, nomadism and the social anthropology of Iran. Page s 611-63 in W. B. Fisher, editor. The Cambridge history of Iran, vol. 1: the land of Iran. Cambridge University Press, Cambridge, UK. http://dx.doi. org/10.1017/CHOL9780521069359.021

Vallentine, J. F. 2001. Grazing management. Academic Press Inc., San Diego, California, USA. 